\title{
Methodology of Estimation of Agro-Industrial Capacity and Food Consumption (As in the Case of the Region of North-Western Federal District of the Russian Federation)
}

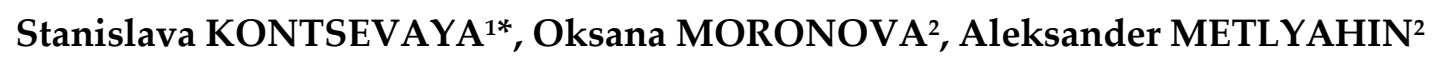 \\ and Lubos SMUTKA ${ }^{1}$ \\ 1 Czech University of Life Sciences, Prague, Czech Republic; s.konsevaya@mail.ru; smutka@pef.czu.cz \\ 2 Vologda State University, Vologda, Russia; metlyahin.ai@yandex.ru; moronova@mail.ru \\ * Corresponding author: s.konsevaya@mail.ru
}

\begin{abstract}
The key factor for food self-provisioning is efficient utilization of agricultural capacity. The goal of the paper is development of integral assessment of food consumption level and agro-industrial capacity in a region. This methodology was tested in the regions of North-Western Federal District of the Russian Federation. Suggested methodology helps estimate producing production and consumption of food, and compare regions with similar social and economic environment. Assessment of food consumption involved such food products as meat, milk, eggs, bread, sugar, vegetable oil and medically recommended rates of consumption of basic food products. In accordance with the suggested methodology assessment of agro-industrial capacity comprised such indicators as cultivated land, stock of cattle and pigs, quantity of drilled fertilizers, growth rate of agricultural production and production volumes of livestock breeding per 1 person. Ranking score of the regions was made by comparing actual data with standard object or scientifically proved indicators. Suggested methodology revealed that all regions of North-Western Federal District suffered from stable decrease of production capacity of agricultural sector, but actual food consumption was growing simultaneously. This growth is provided by import of agricultural products from other regions of the Russian Federation and from abroad.
\end{abstract}

Keywords: regional analysis, agrifood, agriculture, methodology, food security

JELClassification:F52; Q18

\section{Introduction}

Food security is an integral part of national security of a state. First of all estimation of national food security level is intended for recognition of ability of a country to provide for internal needs of the population in main food products, and to develop national food facility. In the process of analyzing national security of regions food security is transformed into the element of living standards of the definite terrain and estimated mostly by the indicators of food availability (physical and economic), and the indicators of consumption of main food products and conformance of this consumption to reasonable rates. Estimation of efficiency of utilization of agricultural capacity of the terrain and ability of food self-provisioning with 
main products (with regard to agricultural specificity) are integral parts of the methodology of estimation of food security reasonable level.

Different indicators (Davis et al., 2014; Eckert \& Shetty, 2011; Lin et al, 2014; Ma et al., 2013; Sohi et al., 2014; Widener, 2013). are utilized in order to estimate economic food availability at micro- and macro-level. Such indicators as inflation rate, exchange rate, customs duties on food and agricultural products, price index numbers and their dynamics are used at macro-level analysis.

An attention should be paid to difference in approaches to determine regional food security. Currently there are two basically different positions on this issue. Some authors (Vermel, 1997; Ostaev, 2020) consider food security of a region as an integral part of national food security only and prove this point of view by absence of limits on transfer of goods and services, and unreasonable course of regional food system on complete self-provisioning. Openness of a region as a social and economic system paves the way to stable cooperation with other regions and in terms of national food security estimation the place of product manufacturing is not of principal importance but conformance with national standards and requirements on quantitative availability and quality characteristics of consumed food is of great importance.

Second approach paves the way to establishing regional food security system completely similar with national ones (Lilov, 2008). In this case the priority is definitely transferred from food self-provisioning to estimation of physical and economic availability of food, but the key element of regional food security system is reasonable utilization of agro-industrial capacity as it provides the basis for development of premises to create proper food security. Some authors consider issues of food self-provisioning important at any level of food security system establishing (Kostiaev, 2012).

In authors' opinion, analysis of food security level in the region should involve estimation of agricultural capacity of a terrain, its relevance and efficiency of its utilization. Research of relations between scale of agricultural production and assurance of regional food security is of definite interest.

Food consumption level is significantly defined by physical and economic availability of food which depends on production cost and production volumes in the region and costs of import of food resources (Gumerov, 2018). Correlation of prices of imported food and in-house production costs regulates scales of regional food sector, but potential ability of production of food resources limited by natural and climate potential of the terrain and established production capacity is as important as abovementioned correlation. As a rule, limiting impact is identified by base material sector and it is shortage of the local food base material which holds potential development of regional food sector. This is why estimation of production capacity of agricultural sector of a region helps reveal trends of alteration of regional food security and forecast alterations in self-provisioning with main food products in a region.

The goal of this research is development of a methodology of ranking regions by the size and efficiency of agricultural capacity utilization and revealing correlation between food 
self-provisioning of a region and actual consumption of food conforming to medically recommended rates.

The objects of the research are:

1. Development of the methodology of integral assessment of agro-industrial capacity of a region and integral assessment of food consumption by population of a region.

2. Test of suggested methodology as in the case of the regions of North-Western Federal District and research of impact of efficiency of agro-industrial capacity utilization in a region on conformance of actual food consumption with medically recommended consumption rates.

The object of the research is level of regional food security, and the subject is the regions of North-Western Federal District.

\section{Methodology}

Traditionally the process of food security level estimation involves conformance of actual food consumption with standard values, which can be equal to medically recommended rates of consumption (or social rates of minimum commodity bundle if terrain is in critical state) (Uskov, 2014). In this case obtained individual indexes are quite disparate and intended for estimation of satisfaction in definite groups of products without making total review, which helps assess common trend of actual consumption of main food products by population.

Suggested methodology provides solution of the problem of integral assessment of conformance of actual food consumption with established standards and comparison of regions with similar social and economic environment and suffering from similar negative or positive impacts of both internal and external factors that provides reasonable estimation of ability of a region to withstand threats to food security. Application of the methodology in dynamics reveals variation of the region's rank that provides reasonable characteristic of food security level of the region by one of criteria.

The main groups of food comprise those products which satisfy need in proteins (meat and meat products, milk and dairy products and eggs), in carbohydrates (bread and cereal products and sugar), and vegetable oils.

In the process of agro-industrial capacity estimation the system of indicators was focused on two main indicators i.e. the size of capacity and effectiveness of capacity utilization. Such indicators as area under crops (with regard to quality of plough lands which is indirectly characterized by volume of applied fertilizers), stock of cattle and pigs, which characterize availability of production units, were used for estimation of potential food production capacities in the region. Estimation of efficiency of utilization of agro-industrial capacities was made on the basis of indicators identifying growth rates of agricultural production and volume of livestock production per 1 person. These indicators were chosen due to specialty of agricultural companies which were traditionally intended for livestock production. 
Ranking score is based upon comparison of objects by each indicator with relative prototype object, which is artificial object having the best characteristics by comparison with other objects or scientifically recommended ones.

Incoming information is a matrix with elements equal to values of chosen indicators. Each $\mathrm{j}$-indicator on $\mathrm{i}$-object is defined by the value $\mathrm{xij}$, that helps generate information matrix for compared objects:

$$
X=\left[\begin{array}{ccc}
x_{11} & \cdots & x_{1 n} \\
\vdots & \ddots & \vdots \\
x_{m 1} & \cdots & x_{m n}
\end{array}\right]
$$

It should be taken into account that considered objects can be characterized by incentive indicators, which increase improves overall estimation of the object's state (for example, production volume), and disincentive indicators, which increase deteriorates overall estimation (for example, production cost per 1 unit of a product). Moreover, utilized indicators might be of different measurement units or measurement scales so preliminary standardization is to be done.

$$
\begin{gathered}
x_{0 j}=\max _{1 \leq i \leq m} x_{i j}, \text { если } X_{j}-\text { incentive indicator; } \\
x_{0 j}=\min _{1 \leq i \leq m} x_{i j}, \text { если } X_{j}-\text { disincentive indicator. }
\end{gathered}
$$

Deviation of the indicator in positive or negative side from scientifically recommended value signifies deterioration of the situation, and initial value of the indicator can be used as standard value.

Standardized characteristics are calculated on the base of initial values of the matrix $X$ and standard values:

$$
\begin{gathered}
y_{i j}=\frac{x_{i j}}{x_{0 j}}, \text { если } X_{j}-\text { incentive indicator; } \\
y_{i j}=\frac{x_{0 j}}{x_{i j}}, \text { если } X_{j}-\text { disincentive indicator. }
\end{gathered}
$$

Estimation d_i is calculated as weighted distance between two points in n-dimensional space, where coordinates of the first point are standard values of the indicator and coordinates of the second point are indicators of i-object:

$$
d_{i}=\sqrt{\sum_{j=1}^{m}\left(y_{i j}-y_{0 j}\right)^{2} w_{j}}
$$

The object which value of $d \_i$ is minimum should be considered the best one, however, in order to improve demonstrativeness and interpretability of obtained assessments the following value can be decided:

$$
R_{i}=\left(1-d_{i}\right) \times 100 \%
$$

This value identifies extent of conformance to possible standard in given specific conditions. 
In this research disincentive indicator is consumption of sugar. Scientifically recommended rates of consumption should be used in case of consumption of sugar, bread and bread products and vegetable oils per 1 person. Standard values for other indicators should be taken from obtained values.

\section{Results}

During research work basic matrixes including the system of indicators, weighting estimation of an indicator and standard values were generated for each analyzed period. The matrix for 2018 is presented as an example (Table 1).

Table 1. Production capacity of agricultural sector of the regions of North-Western Federal District of the Russian Federation (without St. Petersburg) and efficiency of production capacity utilization in 2018

\begin{tabular}{|c|c|c|c|c|c|c|c|c|c|}
\hline \multirow[b]{2}{*}{ Region } & \multicolumn{9}{|c|}{ Indicators } \\
\hline & 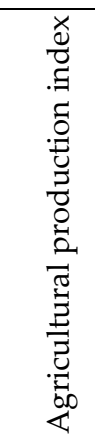 & 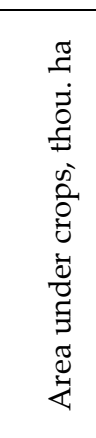 & 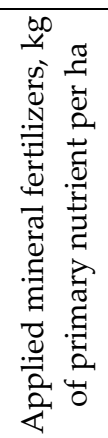 & 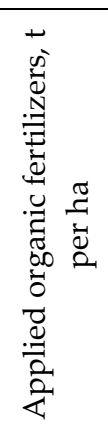 & 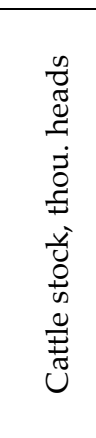 & 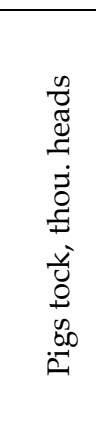 & 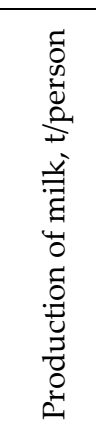 & 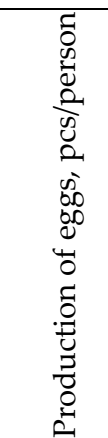 & 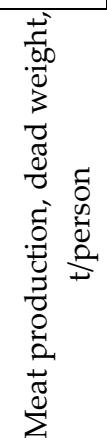 \\
\hline Standard & 110.9 & 355.8 & 121.4 & 10.6 & 165.8 & 204.4 & 0.454 & 438.65 & 0.311 \\
\hline $\begin{array}{l}\text { Weighting of the } \\
\text { indicator }\end{array}$ & 0.113 & 0.101 & 0.069 & 0.069 & 0.094 & 0.094 & 0.153 & 0.153 & 0.153 \\
\hline The Karelian Republic & 102.9 & 30.0 & 18.8 & 4.2 & 22.6 & 7.4 & 0.101 & 12.7 & 0.005 \\
\hline The Komi Republic & 103.3 & 37.2 & 12.7 & 4.0 & 31.6 & 51.8 & 0.066 & 150.4 & 0.029 \\
\hline $\begin{array}{c}\text { The Arkhangelsk } \\
\text { Region }\end{array}$ & 109.0 & 69.4 & 33.4 & 5.6 & 44.0 & 204.4 & 0.112 & 41.1 & 0.005 \\
\hline The Vologda Region & 104.5 & 355.8 & 45.2 & 4.2 & 165.8 & 7.4 & 0.454 & 426.3 & 0.023 \\
\hline The Kalinigrad Region & 110.0 & 249.5 & 121.4 & 3.2 & 137.2 & 51.8 & 0.177 & 265.5 & 0.063 \\
\hline The Leningrad Region & 103.9 & 240.0 & 41.1 & 9.8 & 179.8 & 204.4 & 0.087 & 438.6 & 0.038 \\
\hline $\begin{array}{l}\text { The Murmansk } \\
\text { Region }\end{array}$ & 102.6 & 7.1 & 31.7 & 10.6 & 7.1 & 176.5 & 0.026 & 12.1 & 0.002 \\
\hline The Novgorod Region & 102.4 & 156.0 & 23.6 & 2.7 & 30.6 & 8.0 & 0.109 & 372.2 & 0.202 \\
\hline The Pskov Region & 110.9 & 238.2 & 19.3 & 3.2 & 71.6 & 165.8 & 0.314 & 129.5 & 0.311 \\
\hline
\end{tabular}

Values of indicators were taken from Federal State Statistics Service (Russian Federal statistical website, 2020). The best obtained value of some analyzed region in appropriate period was taken as standard value. The matrix does not involve St. Petersburg for the reason of absence of agricultural production though there is big production capacity of food industry. The Leningrad Region is the main source of basic materials for St. Petersburg.

Estimation of weighting of the indicator was made on the basis of paired comparison method (Table 2). In the process of generating matrix of paired comparison utilization efficiency of production capacity was more considerable than availability of resources needed for establishing of production process. 
Table 2. The matrix of paired comparison of significance of indicators of scale and utilization efficiency of agro-industrial capacity of a terrain

\begin{tabular}{|c|c|c|c|c|c|c|c|c|c|}
\hline \multirow[b]{2}{*}{ Indicator } & \multicolumn{9}{|c|}{ Indicators } \\
\hline & 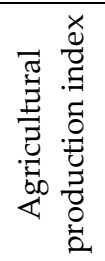 & 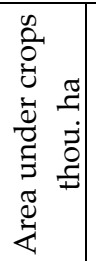 & 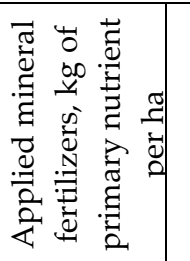 & 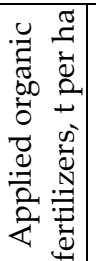 & 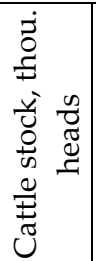 & 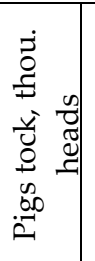 & 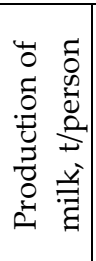 & 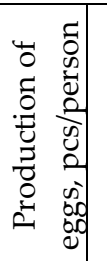 & 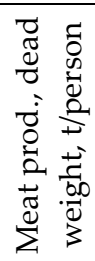 \\
\hline Agricultural production index & $=$ & $=$ & $>$ & $>$ & $>$ & $>$ & $<$ & $<$ & $<$ \\
\hline Area under crops, thou. ha & $=$ & $=$ & $>$ & $>$ & $=$ & $=$ & $<$ & $<$ & $<$ \\
\hline $\begin{array}{l}\text { Applied mineral fertilizers, kg of } \\
\text { primary nutrient per ha }\end{array}$ & $<$ & $<$ & $=$ & $=$ & $<$ & $<$ & $<$ & $<$ & $<$ \\
\hline $\begin{array}{l}\text { Applied organic fertilizers, } \\
\text { t per ha }\end{array}$ & $<$ & $<$ & $=$ & $=$ & $<$ & $<$ & $<$ & $<$ & $<$ \\
\hline Cattle stock, thou. heads & $<$ & $=$ & $>$ & $>$ & $=$ & $=$ & $<$ & $<$ & $<$ \\
\hline Pig stock, thou. heads & $<$ & $=$ & $>$ & $>$ & $=$ & $=$ & $<$ & $<$ & $<$ \\
\hline Production of milk, t/person & $>$ & $>$ & $>$ & $>$ & $>$ & $>$ & $=$ & $=$ & $=$ \\
\hline Production of eggs, pcs/person & $>$ & $>$ & $>$ & $>$ & $>$ & $>$ & $=$ & $=$ & $=$ \\
\hline $\begin{array}{l}\text { Meat production, dead weight, } \\
\text { t/person }\end{array}$ & $>$ & $>$ & $>$ & $>$ & $>$ & $>$ & $=$ & $=$ & $=$ \\
\hline
\end{tabular}

Consequently, the indicators of production of milk, meat, and eggs per 1 person are of maximum significance, agricultural production index is less significant that can be explained by unequal importance of some agricultural products from regional provision's point of view. The indicators of applied fertilizer volume are of minimum importance as they do not influence current food consumption. They impact consumption through soil fertility support and growth of yield of food and fodder crops

Stable trend to decrease of production capacity and efficiency of its utilization in agricultural sector of the regions was observed in the researched period (Fig.1). The Vologda Region had officially leading position till 2014, then its place was taken by The Pskov Region. The Leningrad Region and The Kaliningrad Region have stable high position (3-4 line). The most Northern regions (The Murmansk Region and The Karelian Republic) have expectedly low positions in the rank.

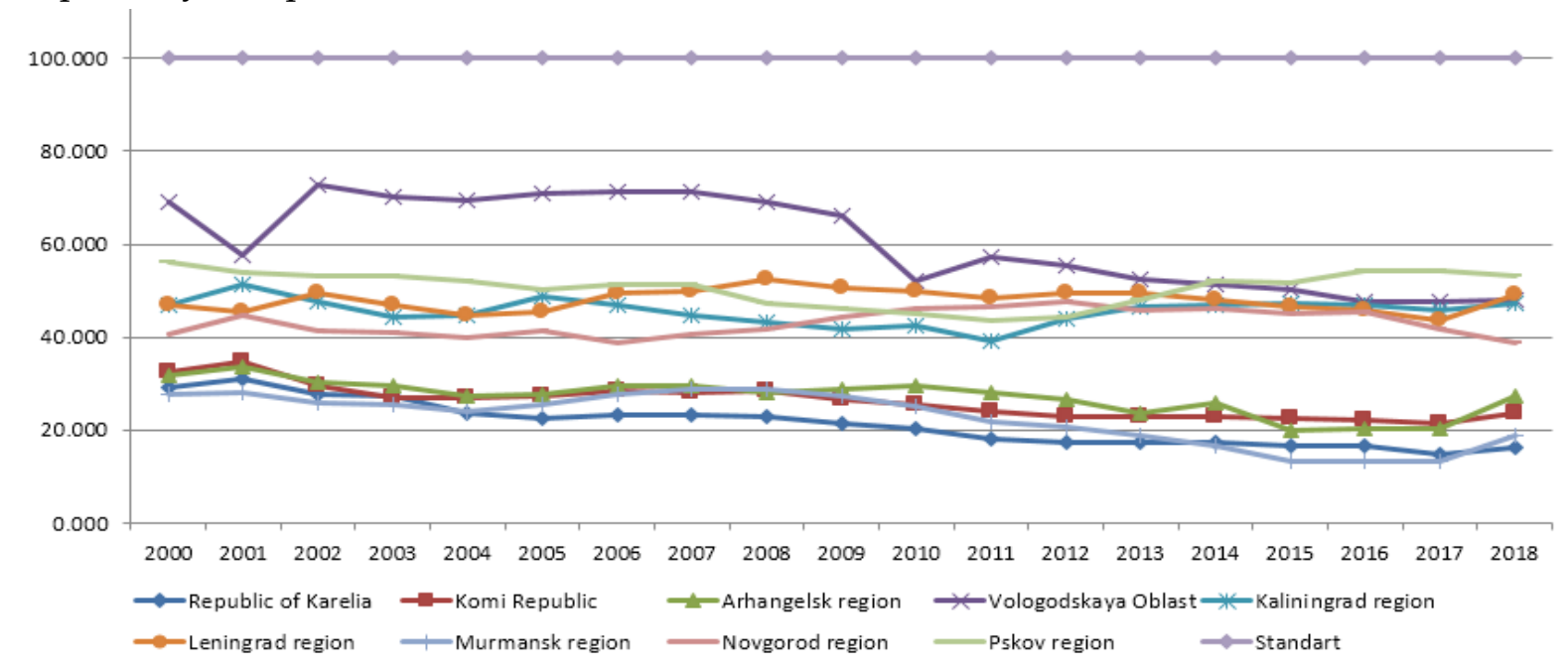

Figure 1. Integral indicator of rate and level of agro-industrial capacity utilization of North-Western Federal District 
Graphic representation of obtained results clearly demonstrates increased deviation of integral indicator of estimation of agro-industrial capacity of a region from standard value. By the end of research period the leader of 2018 The Pskov Region has 1.5 times stronger deviation by comparison with the leader 2000 The Vologda Region (0.466 and 0.310 consequently).

It should be noted that selective growth of agricultural production efficiency in some farms was observed in almost all regions of North-Western Federal District. Special attention should be paid to stability and trend to growth of meat production in The Leningrad Region, The Novgorod Region, The Pskov Region and The Komi Republic (mostly due to pork and poultry production) and milk production in The Vologda Region and The Leningrad Region. Growth of these indicators helped keep leading position in the rank inspite of decreased rate of capacity.

Similar methodology was applied to range regions by conformance of actual food consumption with medically recommended rates (Table 3 and 4). Maximum significance belongs to conformance with threshold values in the group of animal origin food i.e. meat and meat products, milk and dairy products and eggs. This group provides balance of proteins and fats of animal origin which deficit negatively impacts quality and lifetime of the population.

Table 3. Conformance with actual food consumption rates of the population in the regions of

North-Western Federal District (except for St. Petersburg) in 2018

\begin{tabular}{|c|c|c|c|c|c|c|}
\hline \multirow[b]{2}{*}{ Region } & \multicolumn{6}{|c|}{ Indicators } \\
\hline & 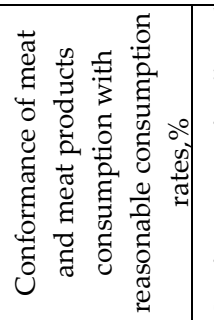 & 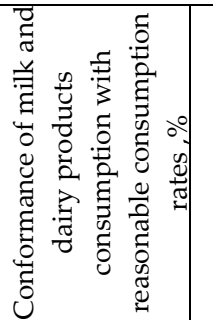 & 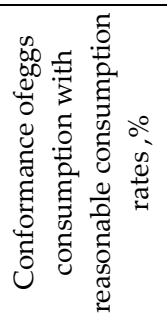 & 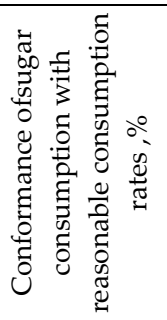 & 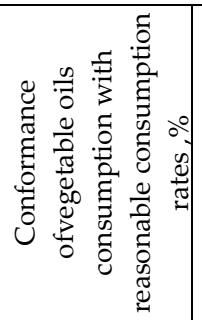 & 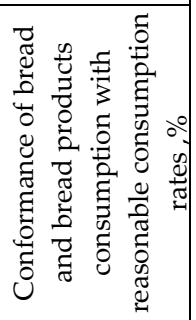 \\
\hline Standard value & \begin{tabular}{l|l}
125.3 & \\
\end{tabular} & \begin{tabular}{|l|l}
84.5 & \\
\end{tabular} & 114.6 & 100 & 100 & 100 \\
\hline $\begin{array}{l}\text { Weighting of the } \\
\text { indicator }\end{array}$ & 0.212 & 0.212 & 0.212 & 0.110 & 0.132 & 0.122 \\
\hline The Karelian Republic & 96.0 & 66.1 & 95.0 & 150.0 & 96.7 & 115.2 \\
\hline The Komi Republic & 109.3 & 77.3 & 107.7 & 121.4 & 98.3 & 100.0 \\
\hline $\begin{array}{c}\text { The Arkhangelsk } \\
\text { Region }\end{array}$ & 85.3 & 55.8 & 92.3 & 139.3 & 108.3 & 100.0 \\
\hline The Vologda Region & 98.7 & 69.7 & 121.5 & 142.9 & 103.3 & 102.9 \\
\hline $\begin{array}{c}\text { The Kaliningrad } \\
\text { Region }\end{array}$ & 116.0 & 68.2 & 109.2 & 160.7 & 117.5 & 101.9 \\
\hline The Leningrad Region & 104.0 & 84.5 & 114.6 & 139.3 & 85.0 & 108.6 \\
\hline The Murmansk Region & 102.7 & 70.0 & 78.5 & 121.4 & 114.2 & 78.1 \\
\hline The Novgorod Region & 100.0 & 69.7 & 104.2 & 139.3 & 122.5 & 106.7 \\
\hline The Pskov Region & 125.3 & 83.9 & 88.5 & 132.1 & 95.8 & 92.4 \\
\hline
\end{tabular}

Consumption of food providing carbohydrates part of allowance significantly influences energy content. Nonconformance of indicators almost 2 times lower than in previous group can be explained by better availability and by redundant consumption of 
some products, in particular sugar. Significance of fats presented by vegetable oils takes average position.

Table 4. The matrix of paired comparison of conformance of actual food consumption

\begin{tabular}{|c|c|c|c|c|c|c|}
\hline \multirow[b]{2}{*}{ Region } & \multicolumn{6}{|c|}{ Indicators } \\
\hline & 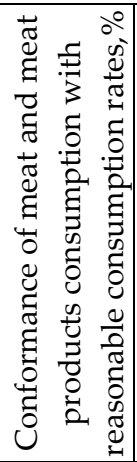 & 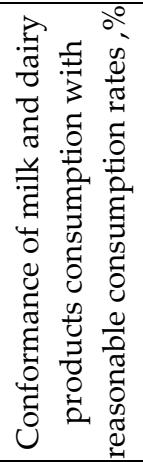 & 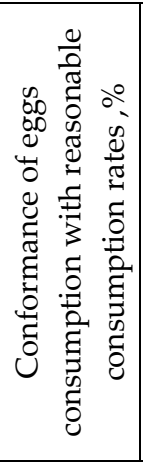 & 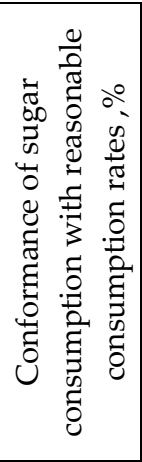 & 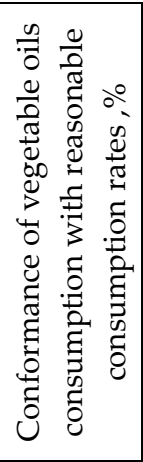 & 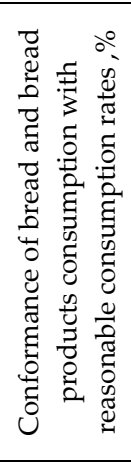 \\
\hline $\begin{array}{l}\text { Conformance of meat and meat } \\
\text { products consumption with reasonable } \\
\text { consumption rates, } \%\end{array}$ & $=$ & $=$ & $=$ & $>$ & $>$ & $>$ \\
\hline $\begin{array}{l}\text { Conformance of milk and dairy } \\
\text { products consumption with reasonable } \\
\text { consumption rates }, \%\end{array}$ & $=$ & $=$ & $=$ & $>$ & $>$ & $>$ \\
\hline $\begin{array}{c}\text { Conformance of eggs consumption } \\
\text { with reasonable consumption rates } \%\end{array}$ & $=$ & $=$ & $=$ & $>$ & $>$ & $>$ \\
\hline $\begin{array}{c}\text { Conformance of sugar consumption } \\
\text { with reasonable consumption rates, } \%\end{array}$ & $<$ & $<$ & $<$ & $=$ & $<$ & $=$ \\
\hline $\begin{array}{c}\text { Conformance of vegetable oils } \\
\text { consumption with reasonable } \\
\text { consumption rates }, \%\end{array}$ & $<$ & $<$ & $<$ & $<$ & $=$ & $=$ \\
\hline $\begin{array}{c}\text { Conformance of bread and bread } \\
\text { products consumption with reasonable } \\
\text { consumption rates }, \%\end{array}$ & $<$ & $<$ & $<$ & $<$ & $=$ & $=$ \\
\hline
\end{tabular}

Integral indicator signifies stable trend of actual food consumption to approach to recommended one, though no regions obtained this standard within researched period.

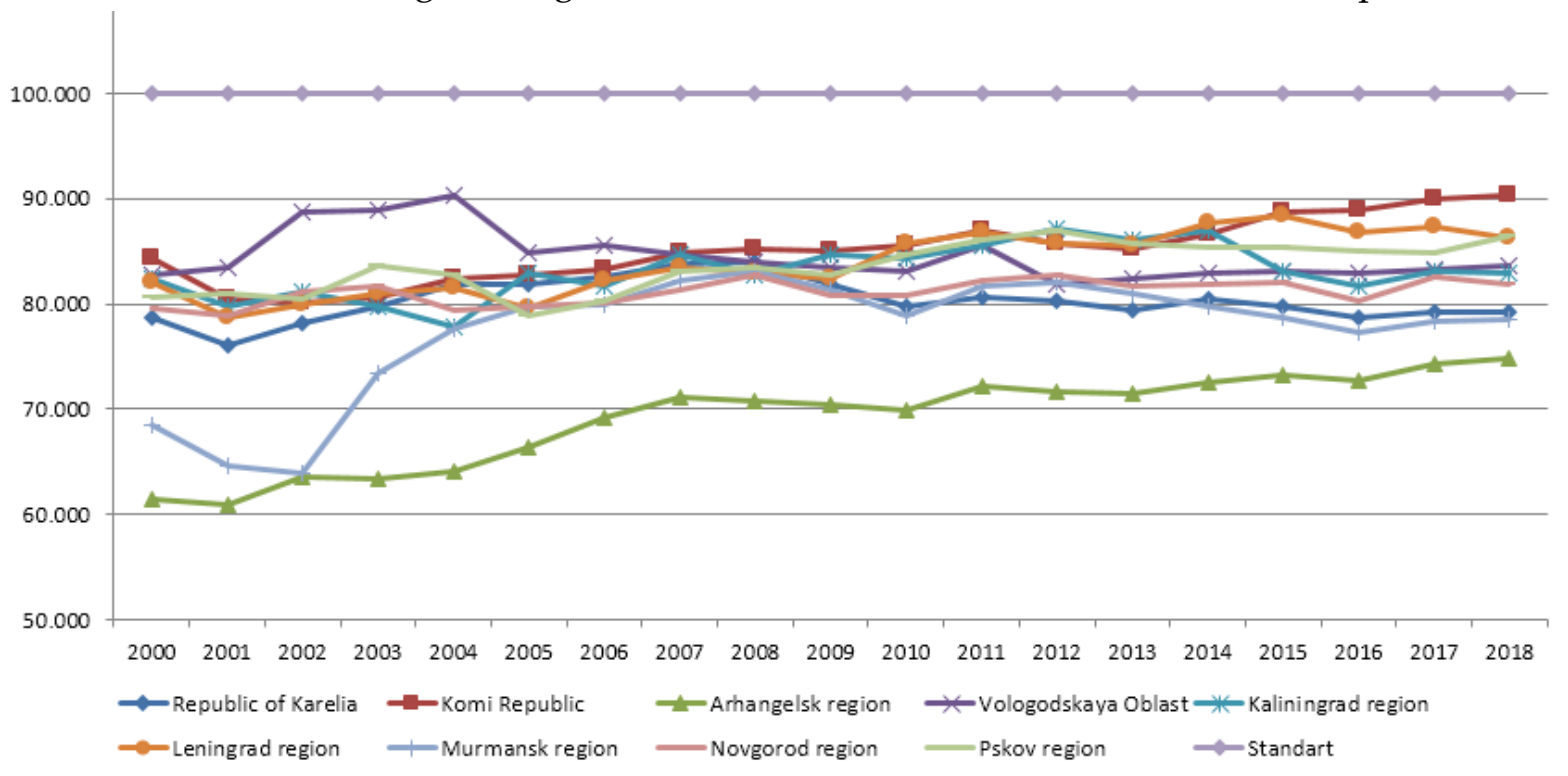

Figure 2. Integral indicator of conformance of actual food consumption with medically recommended consumption rates 
In spite of visual multidirectionality of curves of integral indicators of scale and utilization of agro-industrial capacity of the regions in North-Western Federal District, and integral indicators of conformance of actual food consumption with medically recommended consumption rates there is stable relation between these indicators. Regions with leading position on the first indicator, as a rule, keep high positions on consumption ranking too. Outsiders in self-provisioning with minor exceptions demonstrate maximum deviation from standard values of food consumption. Deficit food products are compensated by import of agricultural products. Import is subdivided into internal one from other Russian regions with better conditions for agriculture and foreign import from Turkey, China and EU (Smutka, et al., 2015) which compensates shortage of agricultural products too.

\section{Discussion}

The term food security is still the question for discussion. Hence, Food Security Doctrine of the Russian Federation (Act no.20, 2020) is based on the concept of food self-provisioning. At the same time self-provisioning with main groups of food products can't be the single criterion of food security level, and in case of meso- and micro-levels this group of indicators needs some addition.

Approaches to identification of food security are different among Russian scientists. (Nazarenko, 2011) defines food security as a complex of sub-systems including food independency, social stability, demographic stability and food production branch. (Ushachev, 2008) distinguished two parts of food security: provision of physical and economic availability of food for each person in conformance with reasonable rates of consumption and in volumes available to support active mode of life, and high quality and safety of consumed food products. Both parts should not depend on variation of external and internal conditions and should not influence government food stocks. Here the main factor of food security provision is increase of food production scale in the country.

In opinion of authors of this research the most complete definition of food security is that one, which was given by (Gumerov, 2003), who considered that food security is "constantly supported state of protection of national food systems from internal and external risks and threats, which provides trouble free provision of all social groups of population with main food products in accordance with right of each person on relevant food conforming to standards of healthy and ultimate nutrition acting in given period of time". This approach helps take into account dynamics of rates and standards which are modified due to social and economic transformations of the society and development of regulatory environment of national food system.

\section{Conclusions}

In other words, the results of the research provide the following main conclusions:

1. Stable relation was revealed between efficiency of functioning of agricultural and food sector in the region and consumption of main food products. 
2. Suggested methodology has such specific features as complexity and universalism which provide an opportunity for comparison analysis of definite criteria of food security by regions, and corrective actions within agricultural and food policy with regard to specific features of terrain's development and revealed risks and threats.

3. Recommended set of indicators and assessment criteria may be transformed by introducing additional indicators and criteria or excluding less efficient ones depending on the goals of the research and significance of representation of agricultural specificity of the region and development of agricultural production.

In modern conditions agricultural and food policy of the country should be formed with regard to the fact that the Russian Federation is under sanctions by some economically developed countries that makes questions of food capacity development in the regions and in the whole country especially actual. So systematic assessment of efficiency of current regulation and support measures by assessment of changes in scale and efficiency of agro-industrial capacity utilization as well is necessary for development of regional agricultural and food policy.

Acknowledgments: This research was supported by the grant of Internal Grant Agency (IGA) of Faculty of Economics and Management, Czech University of Life Sciences, project 2020A0015 entitled "Price changes on agrifood markets in post-Soviet countries under Russian import ban and sanctions".

\section{References}

Act no.20, On approval of the Food Security Doctrine of the Russian Federation. Decree of the President of the Russian Federation 2020. http://docs.cntd.ru/document/564161398

Davis, L., Sengul, O., Ivy, J., Brock, L., \& Miles, L. (2014). Scheduling Food Bank Collections and Deliveries to Ensure Food Safety and Improve Access. Socio-Economic Planning Sciences, 48(3), 175-178. https://doi.org/10.1016/j.seps.2014.04.001

Eckert, J., \& Shetty, S. (2011). Food systems, planning and quantifying access: Using GIS to plan for food retail. Applied Geography, 31, 1216-1223. https://doi.org/10.1016/j.apgeog.2011.01.011

Gumerov, R. (2018). Food security of the Russian Federation (theory and practice). Bukvalno.

Kosiaev, A., \& Kotusenko, I. (2012). Ensuring food security in Russia: a regional aspect. Economy of agricultural and processing enterprises, 5, 4-7.

Lilov, A. (2008). Regional food security problems in Siberia. In Scientific basis for the development and implementation of regional programs for stabilization and development of the agro-industrial complex, systems for conducting agro-industrial production and ensuring food security of the Russian Federation, SibNIIESH (pp. 152-153).

Lin, B., Ver, P., Kasteridis, P., \& Yen, S. (2014). The roles of food prices and food access in determining food purchases of low-income households. Journal of Policy Modeling, 36, 938-952. https://doi.org/10.1016/j.jpolmod.2014.07.002

Ma, X., Battersby, S., Bell, B., Hibbert, J., Barnes, T., \& Liese, A. (2013). Variation in low food access areas due to data source inaccuracies. Applied Geography, 45, 131-137. https://doi.org/10.1016/j.apgeog.2013.08.014

Nazarenko, V. (2011). Food security (in the world and in Russia). Monuments of historical thought.

Ostaev, G., Frantsisko, O., Ternavshchenko, K., Molchan, A., Ovcharenko, N., \& Balashova, I. (2020). Formation of an integrated system for monitoring the food security of the region. Amazonia Investiga, 9(25), 59-70.

Russian Federal statistical website. (2020). Regions of Russia. Socio-economic indicators. Retrieved January 1, 2021 from https://rosstat.gov.ru/

Smutka, L., Spicka, J., Ishchukova, N., \& Selby, R. (2016). Agrarian import ban and its impact on the Russian and European Union agrarian trade performance. Agricultural Economics, 62(11), 493-506. https://doi.org/10.17221/294/2015-AGRICECON

Sohi, I., Bell, B., Liu, J., Battersby, S., \& Liese, A. (2014). Differences in Food Environment Perceptions and Spatial Attributes of Food Shopping Between Residents of Low and High Food Access Areas. Journal of Nutrition Education and Behavior, 46(4), 241-249. https://doi.org/10.1016/j.jneb.2013.12.006 
Ushachev, I. (2008). Ensuring food security is a top priority for the Russian economy. OrelGAU Bulletin, 5(8), 5-10. Uskov, T., Selimenkov, A., \& Anishenko, A. (2014). Food security of the region. ISERT Russian Academy of Science. Vermel, D., \& Hromov, U. (1997). Problems of food security in Russia. International and internal aspects. Agro-industrial complex: economics, management, 1, 5-12.

Widener, M., Metcalf, S., \& Bar-Yam, Y. (2013). Agent-based Modeling of Policies to Improve Urban Food Access for Low-income Populations. Applied Geography, 40, 1-10. https://doi.org/10.1016/j.apgeog.2013.01.003 